\title{
THE NEED FOR EXPATRIATION AND THE PLANNING OF THE PROCESS: ORGANIZATIONAL LOOKS FOR SPORTS
}

\author{
Ivan Wallan Tertuliano ${ }^{1}$ \\ Adventist University Center of São Paulo (Unasp) - São Paulo - Brazil \\ Vivian de Oliveira ${ }^{2}$ \\ University Center FIEO - Osasco - Brazil \\ Vladan Pavlović ${ }^{3}$ \\ University of Pristina, Faculty of Economics, K. Mitrovica, Serbia; \\ Afonso Antonio Machado ${ }^{4}$ \\ São Paulo State University at Rio Claro (UNESP) - Rio Claro - Brazil;
}

\begin{abstract}
This paper focuses on expatriation and its influence on the success and failure of expatriates. Thus, the objective of this essay was to conceptualize the expatriation phenomenon, as business necessity and expatriation planning, in order to point out the relation of such phenomenon to the success and failure of the expatriates in the sporting context. In this perspective, the different perspectives on expatriation and its planning were woven. The present essay concludes by pointing out that the main reasons that companies rely on to send employees to expatriation is related to the improvement of revenue and market growth, which can be understood in sport as something similar. While intrinsic motivations, people accept expatriation much driven by the improvement of life and career, whether a corporate or sporting look. So, this paper suggests that the planning of expatriation is conducted in a cautious manner, avoiding the psychological and financial problems that may cause a premature return of the athlete.
\end{abstract}

Keywords: Expatriation, Sport, International Mission, International Management of Human Resources.

\section{INTRODUCTION}

Guedes (2012) points out that globalization has led companies to expand their contacts with people from other cultures with the aim of establishing partnerships, distributing products and conducting negotiations. With this conduct, the expatriation of employees became a reality, being conducted, at the beginning, without any strategic foundation (Carvalho, 2016). There are a lot of reasons why organizations lead their expatriate staff as well as the reasons why expatriates accept the process (Carvalho, 2016; M. E. Freitas, 2010).

\footnotetext{
${ }^{1}$ correspoding author. ivanwallan@gmail.com

2 vivian_oliveira58@hotmail.com

3 vladan.pavlovic@pr.ac.rs

${ }^{4}$ afonsoa@gmail.com
} 
According to Baruch, Steele and Quantrill (2002), there are three situations that justify companies to expatriate their employees: (a) specific business needs; (b) career development; (c) control over foreign operations. In the first situation, the people who are sent present specific skills or experiences that may be required in the target operation. In the second situation, promising managers go abroad to gain experience in the autonomy and self-sufficiency of managerial activities and return to apply the knowledge in the local operation. In the third situation, it means maintaining control of the subsidiary, that is, maintaining strategic alignment with the parent company.

In addition to this, the literature points out that companies move their employees out of business for reasons of strategic motivation (Bartlett \& Ghoshal, 1992), such as improving their company in new markets, for example. However, it is known that companies seek global leadership strategies, which can be achieved by the expatriation of their employees (Pereira, Pimentel, \& Kato, 2005). As a motivation for expatriation, the literature demonstrates that in addition to the motivations of the company, the expatriate has personal motivations that lead to the acceptance of this process (Martins, 2011). As reasons, Brandão (2012) points to the improvement of salary, the prospect of improvement of position, autonomy, among others, as the factors that encourage the employee to accept the expatriation.

However, for expatriation to occur well, some factors must be taken into account as personal, family and cultural adaptation (Tanure \& Duarte, 2006). Thus, it is observed that companies face difficulties in seeking new markets and that, in addition to the aforementioned problems, there are political problems, business environment, new country culture and legislation (Pereira et al., 2005). Therefore, the companies have difficulty in choosing the employees that have so many adaptations and can leverage the business of the company in the international scope. Thus, the guiding question of the present essay is: what are the factors that most contribute to the success of the expatriate? In order to address this problem, the objective of this essay was to conceptualize the expatriation as a necessity of the companies and to point out the relation of such phenomenon with the success and failure of the expatriates in the sporting context.

With the purpose of presenting and proposing academicprofessional postures, this essay aimed to bring a direction in which classical and contemporary studies were used to weave on the theme and to provide a greater radius of actuation and reflection. Thus, the present essay was based on the methodological design of a qualitative research on the perspective of documentary analysis (Severino, 2007). 


\section{THE EXPATRIATION PROCESS - ORGANIZATIONAL NEED}

Expatriation is a necessary resource for aligning strategies and objectives (Carvalho, 2016) with the aim of:

a) internationalize its management;

b) increase the repertoire of knowledge of specific teams for a specific project and / or unit;

c) to form new leaders;

d) development of individual skills;

e) increase the level of coordination and control of their units;

f) increase the strategic diversity of your recruitment department (Human Resource);

g) develop and learn new techniques and organizational processes;

h) export culture from parent company to subsidiaries, exemplifying important aspects of organizational culture;

i) promote the transfer of knowledge and skills among all the subsidiaries of an organization;

j) to represent the parent company, in international level, through the presence of reliable employees in the subsidiaries;

k) promote professional career development of executives from the parent company;

1) promote the development of a global culture with a view to managing based on the sharing of new ideas, strategies and common practices;

m) to correct the lack of local talent for the exercise of certain functions that require levels of qualification not completed by local employees;

n) satisfy business needs.

Face to the individual motivation to expatriation and the fulfillment of an international mission, the aspects that lead the collaborator to accept, according to Carvalho (2016), are: (a) improvement of the job position; (b) better remuneration and benefits; (c) professional and communication development; (d) greater autonomy and variety of tasks; (e) the possibility of acquiring an overall perspective of the company's operations; (f) career progression; (g) status search; (h) ways of escaping personal and family problems; (i) the taste for adventure, new challenges and cultural contexts; (j) a taste for knowledge sharing and skills development. Such motives have no order of events, and more than one can occur.

Bartlett and Ghoshal (1992) point out the reasons for the expatriation of employees:

a) to understand the local market needs; 
b) leverage opportunities of different factors of national production;

c) develop in the company the exchange of units.

This way, companies send expatriates to international actions to open new markets, facilitate a merger or acquisition, install new technologies and systems, increase market share or stop the advancement of competitors, develop long-term business vision in other countries, transferring knowledge to local professionals, learning and generating innovative ideas, and developing global leadership skills (J. S. Black \& Gregersen, 1999; Pereira et al., 2005).

Besides the motives of the organization, there are the individual motives, that is, those that lead the person to accept be an expatriate. As motives, are found employment opportunities, salary, professional development, autonomy, job search, acquisition of a global perspective of the company, career advancement and the pursuit of corporate ascension etc. (J. P. P. Brandão, 2012; Martins, 2011).

The process of expatriation, according to Baruch and Altman (2002) is given by several factors: (1) global; (2) emissary; (3) peripheral; (4) professional; (5) convenient. In the global factor, the expatriation is seen as part of the life of the company, constituting a stage of the managerial career of the professional. In the emissary factor, the expatriation occurs in the case in which the company maintains markets in other countries; so the origin country of the company continues as the base of the resources of the expatriate and it maintains a strong relationship with the origin country.

In the peripheral factor, expatriation is a post-career option, for employees already retired or retiring. In this case, people seek expatriation as status. On the professional side, expatriation is a strategy for acquiring and developing know-how, focusing on the strengths of the parent company and keeping people within the given rules. Finally, in the convenient factor, expatriation is used as an emerging process for new companies on the global stage. It aims to develop policies and procedures to operate in global markets.

In any given factor, the expatriation is seen as an International Mission (IM), in which the employee changes country in favor of the company. Ivancevich (2008) points out three types of collaborators: a) local staff - coming from the local population; b) an employee - an expatriate worker, that is, transferred from headquarters to a subsidiary; c) foreign official - employee from another country, not from the host country, but is sent to a subsidiary by the host country.

According to the literature, these IMs lead people to two types of displacements: temporary and expatriate (Maike Andresen, Biemann, \& 
Pattie, 2012; Baruch, Dickmann, Altman, \& Bournois, 2013; Carvalho, 2016). Temporary displacement is understood as the departure of the official to another country for a period of less than 6 months. Expatriation is understood as a change of place of work for a period of more than 6 months, usually lasting 3 years (Carvalho, 2016), and can return to the country of origin, after the deadline, being framed to a position compatible (Maike Andresen et al., 2012; Baruch et al., 2013).

Even with these definitions, the authors do not reach a consensus on the minimum time of displacement for the employee to be considered expatriate (Caligiuri, 2000; Dutra, 2002). For Caligiuri (2000), for the employee to be considered expatriate, he must have a minimum stay of 2 years in another country. On the other hand, Dutra (2002) recommends that for the employee to be considered an expatriate, the expatriation must occur for a minimum period of 1 year.

Dickmann and Baruch (2011) present a new model of expatriation, which differs from traditional, short-term assignments, lasting from 3 months to 1 year. The authors argue that this new modality occurs due to the evolution of information and communication systems.

A different categorization for people in IM is suggested by Torrington (1994). In this categorization there are 3 categories:

a) expatriates - live and work in a country other than their native country, for 1 year or more;

b) occasional parachutists - live in another country for a short period of time, usually in the implementation of specific and short-term projects;

c) cosmopolitans - people who travel from country to country, staying in the countries of 1 to 2 weeks and traveling, also called flexipatriates (Baruch et al., 2013; Moreira, Norões, \& Ogasavara, 2014; Rego \& Cunha, 2009).

Another type of expatriate is the so-called volunteer expatriate (Araujo, Teixeira, Cruz, \& Malini, 2012), who are professionals who decide to work in another country on their own initiative (M Andresen, Bergdolt, Margenfeld, \& Dickmann, 2014; Doherty, Richardson, \& Thorn, 2013). This type of expatriation seems to be longer, in length of stay in the other country, than the traditional one (Doherty, Dickmann, \& Mills, 2011), with a duration of more than 6 years. There are also the expatriates called impatriates (Baruch et al., 2013; Rego \& Cunha, 2009). These expatriates are sent from subsidiary companies to host company, for a long period of time, with the purpose of preparing them to occupy management positions in the subsidiaries.

IMs occur through professionals who are sent by the company to live in another country, but that represents the company (Nardi, 2015). 
For Altman and Baruch (2012), the professional who aims to be a global leader has the interest of international experience, taking expatriation to a strategic level for corporation. In addition, it is evident that expatriation is necessary for the growth of the company, so, it is an organizational necessity, since all cited literature refers to the need for expatriation to improve management and competitive advantage.

For Evans, Pucik and Barsoux (2002), IMs can be of a long or short duration, aiming to satisfy the needs or the acquisition of knowledge. When the IM is long-term, its purpose is to represent the parent company (satisfaction of needs) or to develop competences (acquisition of knowledge). If the IM is of short duration, its objective is the satisfaction of needs, trying to solve problems through the expatriation. On the other hand, if the objective is acquisition of knowledge, expatriation is for career progression.

Other factors may influence the expatriation decision. For Brett, Stroh and Reilly (1993) the younger collaborators tend to accept the missions more easily. In addition, the authors point out profiles of contributors contributing to the expatriation decision: (a) those who believe in the future of the career; (b) those who have low wages and; (c) those with a career ambition.

Studies such as Stahl, Miler and Tung (2002) and Suutari and Brewster (2003) point to interesting results. For the authors, married officials make the decision of expatriation influenced by their spouse. In addition, if the spouse is female, the willingness to accept the expatriation is greater, having an individual motivation relationship with the challenge of living and working in a new country (Günter K Stahl \& Cerdin, 2004). Thus, understanding the existence of this diversity of employees in companies, especially in International Human Resources Management (IWRM) is necessary.

In sports, until the $1960 \mathrm{~s}$, it dominated the concept that the team belonged to the fans and that the sport could not be appropriated by the private groups (Machado, 2013). However, this vision was replaced by the vision of business management, in which sport should be a product, a way of raising revenue and, consequently, a profit for clubs and federations (Lima et al., 2018; Tertuliano et al., 2018). This was due to the globalization that the sport suffered, especially after the 1970s, when sports began to be seen as a spectacle sport, that is, an entertainment product transmitted by the media as a form of profit (Proni, 1998).

As a result, companies are starting to take over clubs with the aim of linking their brand and making a profit, generating a new concept of business management within clubs (Lima et al., 2018; Tertuliano et al., 2018). One of the reasons that led to this was that multinational 
companies grew in stratospheric proportions and saw in sport a support to globalize their brands. Associated with this, globalization has led the sport to have high rates of audience in Television, a greater appreciation of the viewers for the sport, the sport has become a universal language, leading companies to want to be present in all markets and convey a nice image and popular (Vlastuin, Almeida, \& MArchi Júnior, 2008).

In the case of Volleyball, we have the examples of the brands Sadia and Pirelli that constituted Volleyball teams, aiming at improving sales of their products and, consequently, increasing profit by the use of the sport (Vlastuin et al., 2008). The same can be observed in Football, a sport that moves amounts in products, which makes countless companies interested in such sport (Machado, 2013). In addition to this, we have the need for clubs to be transnational, which leads them to international transactions, in the context of the "manpower", the player. Thus, the expatriation of players becomes present in the sport, being necessary their understanding.

\section{EXPATRIATION - SUCCESS AND FAILURE}

Tanure and Duarte (2006) point out some aspects that are fundamental in expatriation as personal, family and cultural adaptation. According to the authors, these are the biggest challenges for companies to internationalize and expatriate employees. Regardless of the types of employees, duration and reasons for expatriation, companies face problems when they leave their borders, mainly related to the legislation, political and economic situation, business environment and culture of the new country (Pereira et al., 2005).

In addition to these problems, corporations face difficulties in selecting suitable employees to assume responsibilities for the international business. Most often, the criteria used to select and train expatriates are simple and rigid (Mendenhall \& Oddou, 1985). In most cases, this is due to the belief that the expatriate's success story in his country of origin is the most important prerequisite for developing his work elsewhere, with the same results expected (Mendenhall \& Oddou, 1985; Pereira et al., 2005).

Many of these difficulties occur because companies, for the most part, do not assume that expatriation demands the departure of the professional from their country, leading to the need to adjust to a new culture and work environment (Nardi, 2015), that leads to the need for flexibility, adaptability and tolerance of this professional.

In this view, the success of expatriation, especially in IM, is anchored in three indicators related to adaptation: 
a) work and related activities;

b) relations with people from the new country, inside and outside work;

c) environment and culture (Nardi, 2015; Shaffer, Ferzandi, Harrison, Gregersen, \& Black, 2006).

On this way, professionals who are sent to IM, while expatriates, must present some characteristics, such as ability to communicate, independent of the local language (Holopainen \& Björkman, 2005). In addition, expatriates who experience expatriation tend to be more successful in the process. However, expatriates must undergo training on the culture of the new country to help them perceive this change.

In relation to the failure, some authors point out the early return, the expatriate's stay in the foreign country with low income and the exit of the expatriate from the corporation as failure factors (Martins, 2011; Sousa, 2014). In addition, studies show that the family is among the major causes of expatriation failure (Araujo et al., 2012; J. S. Black \& Gregersen, 1999; Pereira et al., 2005; Sousa, 2014), mainly in relation to the inability of the spouse to adapt to the new cultural environment, followed by remuneration, benefit and compensation policies and practices (J. S. Black \& Gregersen, 1999; Dowling, Festing, \& Engle, 2008; Machado, 2013).

Black, Mendenhall and Oddou (1991) have identified factors that contribute to the intercultural adaptation of expatriates who are related to the employee and to the company. Employee-related factors reflect prior international experience and intercultural training prior to expatriation. The factors related to the company are linked to the mechanisms and criteria for selecting the expatriate. The authors argue for the need for a wide variety of criteria in choosing the expatriate, assuming that this variety contributes to the success of expatriation.

Based on this need, some authors have elaborated models for expatriation planning. According to Bianchi (2011), expatriation planning must follow four stages:

1) Expatriation planning - presentation of the definition of specific objectives, understanding of issues related to the foreign environment and validation of objectives and targets;

2) Pre-expatriation - clear definition and communication of individual objectives, definition and consensus on IM evaluation criteria, awareness of issues related to repatriation and employee and family training;

3) Expatriation - communicating with the expatriate, managing information, reviewing experience, evaluating the process and analyzing opportunities for return; 
4) Repatriation - updating the organization and the environment, evaluating the motivations involved and support for family reorientation. in 8 phases:

Tanure, Evans and Pucik (2007) present the expatriation process

1) identification of the internationalization strategy;

2) clear definition of the purpose of expatriation;

3) selection of candidates for IM;

4) preparation and orientation of possible expatriates;

5) adjustment of the role of the expatriate future;

6) Expatriate performance management;

7) adequate remuneration for the expatriate to give account of the new environment, with the family;

8) repatriation, return preparation.

According to Brandão (2012), all the above mentioned models points out that are inherent to expatriation, which helps define what is to be expatriated, leading to the need to create networks, transmission of know-how and organizational practices. In sports, it seems to be the same, that is, when one assumes that the athlete has similar psychological and social characteristics, one can infer the same characteristics of success and failure mentioned above (M. R. F. Brandão, Magnani, Tega, \& Medina, 2013; Machado, 2013).

Something important to be understood, is that expatriation involves all the people who are in contact with the expatriate. However, living in another country can become a burden for some, an obligation to fulfill, a challenge beyond your psychic abilities. This lack of psychological balance makes people to return prematurely, which can cause financial losses and suffering to those involved. Feelings of defeat, failure, loss of value, shame, guilt, among others, invade the imaginary (M. R. F. Brandão et al., 2013).

Continuing from a sports perspective, it is important to remember that the majority of athletes leaving Brazil are humble and of low age, today we have a flood of athletes under 18 years of age leaving the country (Rodrigues, 2010), which facilitates the lack of culture and, consequently, interferes with their success in another country. In addition, Brazilian athletes, for the most part, imagine that from one moment to another, they can become millionaires and think that acting abroad would lead to this achievement. These facts lead the expatriation process to be understood as inevitable for athletes. 


\section{EXPATIATION AND SPORTS}

In this way, some studies were conducted in the field of sports ( $\mathrm{S}$ Agergaard, 2008; Sine Agergaard \& Ryba, 2014; Faggiani, 2017; Faggiani et al., 2016; L. P. R. Freitas, Costa Neto, Cardoso, \& Ferreira, 2012; Lanfranchi \& Taylor, 2001; Machado, 2013; Pontes, Ribeiro, Garcia, \& Pereira, 2018; Rial, 2008; Richardson, Littlewood, Nesti, \& Benstead, 2012; Rodrigues, 2010; Tertuliano, 2016; Tibbert, Andersen, \& Morris, 2015; Tiesler, 2016). Among the studies cited, it is worth reflecting some of these studies. Brandão et al. (2013) also highlight the interference of these factors related to expatriation on the athlete's performance and success. In a research with of soccer players, the authors concluded that the transition of the player to another country is a complex and often problematic issue, that in the most times has not been considered by players, their entrepreneurs or football clubs.

The authors highlight that issues related to language, climate, culture, distance of people close, expectations imposed and a new team made up of unknown people are challenges that these athletes can face. The ability to adapt to new cultures is one of the most important elements for the success of an expatriate soccer player, so unrealistic perspectives on the new team associated with a lack of information about the country can be problems.

Tibbert, Andersen \& Morris (2015) conducted a case study, trying to understand how the rules, traditions and ideals of a subculture influenced the attitudes, emotions and behaviors of a young soccer athlete. The athlete in question, going through the process of adaptation, realized that to be successful in the club, he needed to adjust the norms, traditions, ideals and imperatives of football culture.

The athlete gained acceptance at the club when he finally internalized the subculture hyper male, as ignoring the injury, playing with pain, subjugating his interests for football and considering physical abuse as a necessary part of the hardening process. This case demonstrates that subcultural ideals of mental toughness mean denying emotion and vulnerability and sacrificing individuality, which inevitably leads to stress, bad recovery and overtraining.

Faggiani et al. (2016) sought to understand the impacts related to the process of adaptation of the individual to a new context for sports activity, through a systematic review. According to the authors, although motivated to a career projection, the expatriate athletes face as main challenges the adaptation to the new style of training of the receiving team, the distance of the family and close people, the difficulty in communicating effectively and the adaptation to customs and the local 
culture. These aspects may interfere with the athlete's mental health and performance, as they face situations of isolation and difficulties in establishing relationships.

However, although it would seems painful for the athlete, expatriation has advantages for the athletes and their teams. Tiesler (2016) discusses the advantages of being an expatriate athlete. Specifically on women's football, the author says that the opportunity to develop the football experience in a different (and often more advanced) context is one of the main reasons for athletes to leave their countries, in addition to playing professionally. In women's football, this experience is perceived as overwhelmingly positive and rewarding by the players themselves and by most of the social agents involved in the process.

The experience of transnational football enables athletes to improve their physical fitness (gain "body capital"), improve their technical skills and physical form derived from the rare privilege of exclusive dedication to women's football, in addition to daily practice and regular high-level competition in a better organized league. Thus, athletes gain greater maturity as players and a broader knowledge of the game, derived from an experience in a socio-culturally distinct context.

For clubs, benefits also exist. With the globalized world market, the transfer of athletes to other countries becomes more and more common. Thus, this phenomenon is in line with the phase in which sports clubs are currently living, especially in the Brazilian scenario, with increasing professionalism. For Machado (2013), starting from the understanding of the changes in the management of the clubs, there are new possibilities for other ways of conducting international transfers of players, including the ways of thinking about the participation of clubs in the management of their talents sports.

The author believe that, even in a profit logic, the management of sports organizations can be aligned with the planning and management of the player's career provided that a strategic view of the management of people in the sport if is taken into account the management of a talent not as a simple product to be marketed. In this way, it is believed that the transfer the players can be a substantial gain for clubs and players, increasing possibilities of financial return and performance, alleviating the possibility of failures in the conduct of the expatriation and repatriation processes.

In summary, the results of the studies cited point to the existence of a complex environment, which is related to interculturality. However, it can be observed that there are few publications on the process of expatriation in sport, which limits the extrapolation of the results found. In addition, most of the research is aimed at Football, making it difficult 
to generalize the results for other sports, given the specificities of the sport and its context as an expatriation of athletes.

\section{FINAL CONSIDERATIONS}

Following the objective of the present essay that was to conceptualize the expatriation phenomenon, as a necessity of the companies and to point out the relation of such phenomenon with the success and failure of the expatriates in the sporting context, can be observed some notes that the literature brings about the expatriation process, as reasons for acceptance, reasons for success and reasons for failure. Thus, as reasons for expatriation, the literature points out that the motives of the corporation, while growth and market increase are found as primordial for such process (Carvalho, 2016; Gallon \& Antunes, 2015; Sousa, 2014), but not the only ones .

As motives, expatriates also have reasons to accept such a process (Prestes \& Grisci, 2016), as the search for salary increases, career improvements, new cultures, etc. (Carvalho, 2016). In addition, the number of expatriates grows each year, generating a flood of expatriates (Sebben, 2009). Thus, considering the concept of expatriation as vast and complex, it is important to understand the implications inherent in the existence of this diversity of expatriation situations in multinational companies and sports clubs, in relation to the policies and practices of International Human Resources Management (IHRM) for (in)success in the expatriation process, be it in the corporate world or in sports.

Finally, the present study presents the limitation of studying nonsports studies to conceptualize the phenomenon, which limits its generalization to the sport context. In addition, there are few studies about the subject in the sports field, which demonstrates the need for new studies, but focused on the sport context. However, it is believed that the notes of this essay may contribute to studies aimed at understanding the process of success and failure in athletic expatriation, as well as serve as a conceptual basis for companies and clubs that want to assertively plan the expatriation process of athletes, since the literature demonstrates that both win with the expatriation planning, that is, both the club and the athlete win with the expatriation planning.

\section{REFERENCES}

1. Agergaard, S. (2008). Elite athletes as migrants in Danish women's handball. International Review for the Sociology of Sport, 43(1), 5-19. 
2. Agergaard, S., \& Ryba, T. V. (2014). Migration and Career Transitions in Professional Sports: Transnational Athletic Careers in a Psychological and Sociological Perspective. Sociology of Sport Journal, 31(2), 228-247.

3. Altman, Y., \& Baruch, Y. (2012). Global self-initiated corporate expatriate careers: a new era in international assignments? Personnel Review, 41(2), 233-255.

4. Andresen, M., Bergdolt, F., Margenfeld, J., \& Dickmann, M. (2014). Adressing International Mobility Confusion - Developing Definitions and Differentiations for Self-Initiated and Assigned Expatriates as Well as Migrants. The International Journal of Human Resource Management, 25(16), 2295-2318.

5. Andresen, M., Biemann, T., \& Pattie, M. W. (2012). What makes them move abroad? Reviewing and exploring differences between self-initiated and assigned expatriation. The International Journal of Human Resource Management, 26(7), 1-16.

6. Araujo, B. F. V. B., Teixeira, M. L. M., Cruz, P. B., \& Malini, E. (2012). Adaptação de expatriados organizacionais e voluntários: similaridades e diferenças no contexto brasileiro. Revista de Administração, 47(4), 555-570.

7. Bartlett, C. A., \& Ghoshal, S. (1992). What is a global manager? Harvard Business Review, 70(5), 124-132.

8. Baruch, Y., \& Altman, Y. (2002). Expatriation and repatriation in MNCS: A taxonomy. Human Resource Management, 41(2), 239259.

9. Baruch, Y., Dickmann, M., Altman, Y., \& Bournois, F. (2013). Exploring international work: types and dimensions of global careers. The International Journal of Human Resource Management, 24(12), 2369-2393.

10. Baruch, Y., Steele, D. J., \& Quantrill, G. A. (2002). Management of expatriation and repatriation for novice global player. International Journal of Manpower, 23(7), 659-671.

11. Bianchi, E. M. P. G. (2011). Gestão e Carreira Internacional. Repatriação-construindo elos entre ciclos. In $X X X V$ Encontro nacional dos programas de pós-graduação em administração. Rio de Janeiro: CD-ROM.

12. Black, J. S., \& Gregersen, H. B. (1999). The Right Way to Manage Expats. Harvard Business Review, 77, 52-63.

13. Black, S. J., Mendenhall, M., \& Oddou, G. (1991). Toward a Comprehensive Model of International Adjustment: an Integration of Multiple Theoretical Perspectives. The Academy of Management Review, 16(2), 291-317. 
14. Brandão, J. P. P. (2012). Processos de Expatriação na Gestão Internacional de Recursos Humanos (GIRH): Fatores que influenciam a performance dos expatriados. [Mestrado]. Porto: Universidade do Porto, Porto.

15. Brandão, M. R. F., Magnani, A., Tega, E., \& Medina, J. P. (2013). Além da cultura nacional: o expatriado no futebol. Revista Brasileira de Ciência e Movimento, 21(2), 177-182.

16. Brett, J. M., Stroh, L. K., \& Reilly, A. H. (1993). Pulling up roots in the 1990S - Whos willing to relocate. Journal of Organizational Behavior, 14(1), 49-60.

17. Caligiuri, P. M. (2000). Selecting expatriates for personality characteristics: a moderating effect of personality on the relationship between host national contact and cross-cultural adjustment. Management International Review, 40(1), 61-80.

18. Carvalho, S. M. S. (2016). A relação entre a gestão da carreira e a expatriação: um estudo quantitativo com repatriados portugueses. [Mestrado]. Vila do Conde: Instituto Politécnico do Porto, Vila do Conde.

19. Dickmann, M., \& Baruch, Y. (2011). Global Careers. Oxon: Routledge.

20. Doherty, N., Dickmann, M., \& Mills, T. (2011). Exploring the motives of company-backed and self-initiated expatriates. The International Journal of Human Resource Management, 22(03), 595-611.

21. Doherty, N., Richardson, J., \& Thorn, K. (2013). Self-initiated expatriation and self-initiated expatriates: Clarification of the research stream. Career Development International, 18(1), 97112.

22. Dowling, P. J., Festing, M., \& Engle, A. D. (2008). International human resource management: Managing people in a multinational context (5th ed.). Cengage Learning.

23. Dutra, J. S. (2002). Gestão de Pessoas: Modelo, Processos, Tendências e Perspectivas. São Paulo: Atlas.

24. Evans, P., Pucik, V., \& Barsoux, J. L. (2002). The Global Challenge-Frameworks for International Human Resource Management. New York: McGraw-Hill.

25. Faggiani, F. T. (2017). O processo de aculturação e a adultez emergente em atletas de Futebol. [Doutorado]. Porto Alegre: Pontífica Universidade Católica do Rio Grande do Sul, Porto Alegre.

26. Faggiani, F. T., Strey, A., Fuginiti, D., Lindern, D., Aiquel, P. F., \& Sartori, C. (2016). O Fenômeno do Expatriado no Contexto 
The need for expatriation and the planning of the process: organizational ...

Esportivo. Psicologia: Ciência e Profissão, 36(3), 738-747.

27. Freitas, L. P. R., Costa Neto, J. R., Cardoso, R. M., \& Ferreira, M. P. P. (2012). Estudo do fenômeno do regresso de ex-atletas sulmineiros de futebol do exterior. Lecturas: Educación Física y Deportes, 16(164), 1-9.

28. Freitas, M. E. (2010). Expatriação Profissional: O Desafio Interdependente para Empresas e Indivíduos. Revista Gestão e Sociedade, 4(9), 1-20.

29. Gallon, S., \& Antunes, E. D. D. (2015). Processo de Expatriação: um modelo com fases e práticas. Revista Eletrônica de Estratégia \& Negócios, 8(2), 54-84.

30. Guedes, B. M. D. (2012). Stresse Em Expatriados - Transpor As Fronteiras De Si-. [Mestrado]. Lisboa: Universidade Lusófona de Humanidades e Tecnologias, Lisboa.

31. Holopainen, J., \& Björkman, I. (2005). The personal characteristics of the successful expatriate. Personnel Review, 34(1), 37-50.

32. Ivancevich, J. M. (2008). Gestão de Recursos Humanos (10th ed.). São Paulo: McGraw-Hill.

33. Lanfranchi, P., \& Taylor, M. (2001). Moving with the Ball: the migration of the professional footballers. Oxford: Bloomsbury Academic

34. Lima, E. M. R., Oliveira, V., Pavlović, V., Fischer, C. N., Machado, A. A., \& Tertuliano, I. W. (2018). The Influence of Expenditures in Football Industry Results: Case Study of the Brazilian Football League. Management:Journal of Sustainable Business and Management Solutions in Emerging Economies, 23(1), 1-12.

35. Machado, F. S. (2013). Gestão de pessoas interncional no contexto esportivo brasileiro: uma análise dos processos de expatriação e repatriação de jogadores em um clube de futebol gaúcho. [Mestrado]. Porto Alegre: Universidade Federal do Rio Grande do Sul, Porto Alegre.

36. Martins, D. (2011). Gestão e Retenção de Repatriados: Um Estudo empírico em empresas portuguesas. [Mestrado]. Porto: Faculdade de Economia do Porto, Porto.

37. Mendenhall, M., \& Oddou, G. (1985). The Dimensions of Expatriate Acculturation: A Review. The Academy of Management Review, 10(1), 39-47.

38. Moreira, M. Z., Norões, J. L., \& Ogasavara, M. H. (2014). Framework of the Expatriation Strategy in the sphere ot the individual, of the organisation and of the international 
environment. Revista Eletrônica de Negócios Internacionais, 9(1), 83-102.

39. Nardi, L. M. R. (2015). O perfil do profissional auto-expatriado e a percepção de gestores de recursos humanos sobre este perfil. [Mestrado]. Universidade Católica do Rio Grande do Sul, Porto Alegre.

40. Pereira, N. A. F., Pimentel, R., \& Kato, H. T. (2005). Expatriação e estratégia internacional: o papel da família como fator de equilíbrio na adaptação do expatriado. Revista de Administração ContemporâNea, 9(4), 53-71.

41. Pontes, V. S., Ribeiro, C. H. V., Garcia, R. M., \& Pereira, E. G. B. (2018). Migração no Voleibol brasileiro: a perspectiva de atletas e treinadores de alto rendimento. Movimento, 24(1), 187-198.

42. Prestes, V. A., \& Grisci, C. L. I. (2016). Autoexpatriação: uma compreensão à luz dos movimentos de territorialização, desterritorialização e reterritorialização. In IX Congresso Brasileiro de Estudos Organizacionais. Porto Alegre.

43. Proni, M. W. (1998). Esporte-espetáculo e futebol-empresa. Universidade Estadual de Campinas, Campinas.

44. Rego, A., \& Cunha, M. P. (2009). Manual de Gestão Transcultural de Recursos Humanos. Lisboa: RH Editora.

45. Rial, C. (2008). Rodar: a circulação dos jogadores de futebol brasileiros no exterior. Horizontes Antropológicos, 14(30), 21-65.

46. Richardson, D., Littlewood, M., Nesti, M., \& Benstead, L. (2012). An examination of the migratory transition of elite young European soccer players to the english premier league. Journal of Sport Sciences, 30(15), 1605-1618.

47. Rodrigues, F. X. F. (2010). O fim do passe e as transferências de jogadores Brasileiros em uma época de globalização. Sociologias, 12(24), 338-380.

48. Sebben, A. (2009). O preparo do atleta de futebol. Retrieved May 17, 2015, from http://universidadedofutebol.com.br/andreasebben-psicologa-parte-1/

49. Severino, A. J. (2007). Metodologia do Trabalho Científico (23rd ed.). São Paulo: Cortez.

50. Shaffer, M. A., Ferzandi, L. A., Harrison, D. A., Gregersen, H., \& Black, J. S. (2006). You can take it with you: individual differences and expatriate effectiveness. Journal of Applied Psychology, 91(1), 1-35.

51. Sousa, A. F. B. (2014). A adaptação intercultural da família: um estudo exploratório com expatriados portugueses. [Mestrado]. Vila do Conde: Instituto Politécnico do Porto, Vila do Conde. 
52. Stahl, G. K., \& Cerdin, J. L. (2004). Global careers in French and German multinational corporations. Journal of Management Development, 23(9), 885-902.

53. Stahl, G. K., Miller, E. L., \& Tung, R. L. (2002). Toward a Boundaryless Career: A Closer Look at the Expatriate Career Concept and the Perceived Implications of an International Assignment. Journal of World Business, 37, 216-227.

54. Suutari, V., \& Brewster, C. (2003). Repatriation: empirical evidence from a longitudinal study of careers and expectations among finnish expatriates. International Journal of Human Resource Management, 14(7), 1132-1151.

55. Tanure, B., \& Duarte, R. G. (2006). O impacto da diversidade cultural na gestão internacional. In B. Tanure \& R. G. Duarte (Eds.), Gestão Internacional (pp. 193-220). São Paulo: Saraiva.

56. Tanure, B., Evans, P., \& Pucik, V. (2007). Virtudes e pecados capitais: a gestão de pessoas no Brasil. Rio de Janeiro: Elsevier.

57. Tertuliano, I. W. (2016). Processo de expatriação de voleibolistas: Concepções Bioecológicas. [Doutorado]. Rio Claro: Universidade Estadual Paulista, Rio Claro.

58. Tertuliano, I. W., Lima, E. M. R., Oliveira, V., Pavlovic, V., Machado, A. A., \& Fischer, C. N. (2018). Do financial results influence sports results in football industry? - Case study of the Brazilian football league. Industrija, 46(1), 97-114.

59. Tibbert, S. J., Andersen, M. B., \& Morris, T. (2015). What a difference a "Mentally Toughening" year makes: The acculturation of a rookie. Psychology of Sport and Exercise, 17, 68-78.

60. Tiesler, N. C. (2016). Three types of transnational players: differing women's football mobility projects in core and developing countries. Revista Brasileira de Ciências do Esporte, 38(2), 201-210.

61. Vlastuin, J., Almeida, B. S., \& MArchi Júnior, W. (2008). O Marketing Esportivo na gestão do Voleibol brasileiro: Fragmentos teóricos referentes ao processo de espetacularização da modalidade. Revista Brasileira de Ciência Do Esporte, 29(3), 924. 